\title{
Efforts To Increase The Learning Outcomes Of Biology Through The Methods Of Cooperative Learning Type Group Investigation
}

\author{
Kurnia Putra ${ }^{1} *$ \\ *Coresponding \\ Email : kurniaputra.mpd@gmail.com
}

Fakultas Keguruan dan Ilmu Pendidikan, Universitas Islam Labuhan Batu, Rantauprapat

\begin{abstract}
This study aims to improve student learning outcomes through the implementation of cooperative learning Group Investigation. This research is a classroom action research (Classroom Action Research) conducted in two cycles. Each cycle consists of four stages, namely planning, action, observation, and reflection. The subject of the research is all students as much as 352 students of VII-1 to VII-10 SMP Negeri 1 Rantau Utara, while its object is the students of class VII-1 as many as 34 students. The research Data is obtained through the provision of test, questionnaire, observation, and interview. The technique of data analysis is the technique of cooperative. The results showed increase in the percentage of student learning outcomes based on the test in the classical style for the initial test of $00,00 \%$ (category have not yet succeeded), the first cycle of 52,94\% (category have not yet managed) and cycle II 91,18\% (the category of work), which indicates an increase. The conclusion from this research is that the implementation of cooperative learning Group Investigation can improve the ability of learning outcomes biology class VII-1 SMP Negeri 1 Rantau Utara
\end{abstract}

Keywords: Group Investigation, Learning Outcomes

\section{INTRODUCTION}

The result of learning is a change in behavior acquired learners after experiencing and learning activities. The results of study quality include all the realm of psychological change as a result of experience and learning process of students (Syah, 2001). The results of the study are the actual achievements displayed by the child, while learning outcomes are influenced by the magnitude of the work done by the students.

The results of the study also influenced the intelligence and mastery of early child about the material that will be studied. The success of the student in the learning process can be seen from the results of the study of the individual. Learning outcomes is a measure of the number or size of facts that describes the degree of quality, quantity, and the existence of the state of the student. The process of learning and learning outcomes are two things that can not be separated. Learning outcomes can be influenced by the learning process of the students themselves. Active learning students are viewed as subjects not objects and learn more emphasis than teaching. The students participate and do for themselves what is being studied. While in the learning refers to learning is active, the function of the teacher is to create a 
condition of learning that allows students to develop optimally. Cooperative learning is active learning that emphasizes the activity together as a group and not individually.

Students in groups to develop the prowess of his life, such as finding and problem solving, decision making, logical thinking, communicate effectively and work together (Judge, 2008). Furthermore, the activities of students in learning cooperative, among others, follow the teacher's explanations are active, complete the tasks in groups, give an explanation to your group, encourage your friends a bunch of those to actively participate and discuss (Asthma, 2009). From the above quotation it can be said that cooperative learning is one of learning model that allows students to be active in the learning activities that teachers can use in the conduct of the activities of the learning in the classroom. There are some type of cooperative learning model developed by experts including the type STAD (Student Teams Achievement Divisions), type Jigsaw or a Team of Experts, and GI (Group Investigation) or Investigation Group and the type of Approach Sktruktural (Arends, 2008). There are still many students who do not understand the concept of the material Contamination of the Environment so that when the test of their value is not complete.

One of the cooperative learning model is a learning type of GI (Group Investigation) or the Investigative Group is one type of cooperative learning that is designed by Hebert Thelen. Then this model is extended and developed by Sharan and his colleagues at Tel Aviv University. In the cooperative learning model GI (Group Investigation), the learning activities allow students to develop an understanding of the students through various activities. Which learning activities begins with giving the problems given by the teacher.

The idea of investigation is a good basis for learning Biology itself and in terms of the usefulness of Biology to expand the knowledge and problems in all fields (Setiawan, 2006). With the investigation of Biology, students actively mengkostruksi or reconstruct their knowledge and able to apply in solving the problem. Cooperative learning Model GI (Group Investigation) more emphasis on the students to the problems given by the teacher. In this case the teacher only as a guide for students to find and solve the given problem, so that students more active in learning.

Active learning is a teaching activity that gives students the chance to interact with the subjects studied. Students actively learn the material learning that prepares students to live, the information received is long remembered and stored, and enjoy the ambiance of a cozy classroom, cooperative learning is active learning that emphasizes the student activity together as a group and not individually.

\section{RESEARCH METHODS}

This study uses a class action research (PTK). In this research, applied learning jooperatif type GI. Such actions are given by the teacher or by the direction of teachers conducted by the students.

Research action class using the spiral model of Kemmis and Teggart app developed by Stephen Kemmis and Robin MC Taggart which consists of cycles and each cycle using the four components of the action, i.e. action planning, implementation of action, observation, and reflection related.

\section{A. First Cycle}

\section{Plan Of Action}

a. Make Learning Implementation Plan (RPP) about the material that will be taught in accordance with the Cooperative learning model GI (Group Investigation) are used. RPP useful as a guide teachers in implementing the learning activities in the classroom. 
b. Compile and prepare the observation sheet with the guidance of the lecturer.

c. To develop guidelines for the interview and sheet questionnaire for students. Sheets of questionnaires and interview guidelines that facilitate research to determine how the students ' response to the learning activities.

d. Prepare questions quiz and tests to students which was compiled by researchers with the guidance of the lecturer and the consideration of the teacher concerned.

\section{The Implementation Of The Action}

The actions carried out by using the planning guide that has been created and in the implementation is flexible and open to changes. While researchers will be assisted by one observer who observes the independence of student learning and observing the students ' response to the implementation of learning using learning model GI (Group Investigation) in the classroom.

\section{Observation}

Observations carried out during the learning process in the class by using the observation sheet that has been made. Observation was done to see how the independence of student learning and students ' response to the implementation of learning using a model of learning GI (Group Investigation) in the classroom. After that give the questionnaire to the students.

\section{Reflection}

The Data obtained on the observation sheets were analyzed. Then do the reflection. The implementation of reflection in the form of a discussion between the researchers and teachers of biology concerned. The discussion aims to evaluate the results of actions that have been carried out by assessment of the processes that occur, the problem that arises, and all things related to the actions performed. After that find the way out to the problems that may arise so that you can plan improvements in cycle II.

\section{B. The Second Cycle}

The activities carried out in the second cycle is intended as an improvement from the first cycle. In the second cycle also through the stages of action planning, implementation of action, observation as an improvement based on the results of reflection on the first cycle.

The Data obtained in this study in the form of data observations in the learning process, the results of the questionnaires, and field notes. Additional Data for consideration obtained from interviews with teachers and students who performed at the end of the activity. Data analysis in this research is done in the following way:

1. The analysis of the observation data

The Data observation analyzed in kualitatf to describe the activity of students in learning activities.

2. Analysis of questionnaire data

Questionnaire independence of student learning is given at the end of cycle II. The results of the questionnaire independence of student learning analyzed through the steps :

a. Each item statement questionnaire are grouped in accordance with aspects of the observed, namely, designing learning, evaluate learning, self-confidence, initiative, responsibility, and the nature of authenticity. 
b. Calculated the total score of each of the statement in accordance with aspects of the observed. The total score obtained on each and every aspect then calculated the percentage. How to calculate the percentage of the questionnaire as follows :

$\mathrm{PSA}=\frac{\mathrm{S}}{J S \mathrm{XSM}} \times 100 \%$

Description:

PSA : Percentage Score Of The Results Of The Questionnaire

S : The Overall score Obtained by Student

JS : Number Of Students

SM : Maximum Score

3. Analysis of the results of the interview

The results of interviews with teachers and students were analyzed by qualitative descriptive to complete from the results of the questionnaire so that the obtained data about the students ' response to learning more accurately.

4. Analysis of the results of the test study

Data the results of the test the end of the cycle, dianalisisis quantitatively and qualitatively by comparing the results at the end of every cycle. Based on the score results of the test the end of the cycle for each student determined the average score of the following :

a. Calculate The Average:

Average calculate the results of the study (pre-test and post-test) can be calculated by using the formula:

$\mathrm{X}=\frac{\sum x}{n}$

Description:

$\mathrm{X} \quad=$ The average learning outcomes

$\sum x=$ The amount of the total score of learning outcomes

$n \quad=$ The number of students overall.

b. Calculate the percentage of the number of students who have completed the learning outcomes, by using the following formula:

Mastery Learning $=\frac{\sum S w a}{\sum S w a_{t o t}} \times 100 \%$

Description :

Mastery Learning $=$ learning Completeness in classical

$\sum S w a=$ Students who earn a level of mastery

$\sum S w a_{t o t}=$ Number of students

\section{RESULTS AND DISCUSSION}

The following is a Table of assessment on treatment early, cycle I and cycle II in action research of this class This research was conducted in six meetings with four lessons and two tests (pre-test and post-test). The pre test was carried out at the first meeting with square and rectangular material and the post test was carried out at the last meeting with cube and block material. 
Table 1. Description the Value on the Research

\begin{tabular}{cccc}
\hline No & Description Value & The Average Value & Mastery Learning (\%) \\
\hline $\mathbf{1}$ & Initial value & 30.74 & 00.00 \\
$\mathbf{2}$ & Cycle I & 59,85 & 52,94 \\
$\mathbf{3}$ & Cycle II & 82,21 & 91,18 \\
\hline
\end{tabular}

The application of learning with cooperative learning model type of GI (Group Investigation) improve learning outcomes for biology students materials environmental pollution. Based on the results of the study, before dberi measures the average initial test class is 30,74 (category less) with the levels of the classical completeness $00,00 \%$ (the category has not been successful). After a given action I use cooperative learning model type of GI (Group Investigation) the filing of the problem of the average value of the test problem solving skills I increased to 59,85 (the category of pretty) with the level of the classical completeness 52,94\% (the category has not been successful). This means increased to 53\% (enough) of the initial test performed. Then after administration of act II, where the learning is still with cooperative learning model type of GI (Group Investigation) with the help of the filing of the problem is obtained the average value of the test problem solving skills II students is 82,21 (category better) with the classical completeness $91,18 \%$ (the category of work) which means it has increased from $91 \%$ (better) on the test I.

Research using learning model of group investigation method can improve student learning outcomes in line theory says that the learning model group investigation is one of the alternative learning that can take aim at students ' critical thinking and increase student collaboration in group work.

\section{CONCLUSION}

Based on the results of the analysis of each cycle and discussion, it can be concluded that:

1. Cooperative learning Model type GI (Group Investigation) can improve the learning activities of students of class VII-1 SMP Negeri 1 Rantau Utara on material environmental pollution. It is seen from the average activity cycle reaches 59,85 (katagori) and increased by 82,21 (the category of better) in cycle II.

2. Cooperative learning Model type GI (Group Investigation) can improve the learning activities of students of class VII-1 SMP Negeri 1 Rantau Utara on material environmental pollution. The improvement of learning outcomes obtained from the test results of the actions of each cycle, where the cycle reaches 52,94\% (category have not yet succeeded), and cycle II reached $91,18 \%$ (category successfully). Cooperative learning Model type GI (Group Investigation) is accomplished in accordance with the scenario of learning in class VII-1 SMP Negeri 1 Rantau Utara. The feasibility of the cycle reaches an average of $52,94 \%$ (category have not yet succeeded), and cycle II reached an average of $91,18 \%$ (category successfully). 
Email : editorijhess@gmail.com

\section{REFERENCES}

Arends, Richard I. 2008. Learning To Teach (Belajar Untuk Mengajar). Yogya pustaka belajar

Asma, Nur. 2009. Implementasi pembelajaran dengan pendekatan reciprocal teching sehingga upaya meningkatkan kemendirian belajar matematika dan hasil belajar matematika untuk pokok bahasan kebangunan pada siswa kelas IX-1 SMP Neg. 1 Pacitan. (Skripsi). Yojajarta : UNY

Setiawan. 2006. Pembelajaran Biologi. http.//www.p3gmatyo.go.id. (diakses : 18 April 2014).

Syah, Muhibbin. 2001. Psikologi Belajar, Jakarta : PT. Logos Wacana Ilmu. 